Jurnal Laut Khatulistiwa, Vol. 4 No. 2 (Juli, 2021), Hal. 17-21.

ISSN : 2614-6142 (Printed), 2614-8005 (Online)

http://jurnal.untan.ac.id/index.php/lk

JURNAL LAUT

KHATULISTIWA

\title{
Isolasi dan Karakteristik Bakteri Penambat Nitrogen dari Rizosfer Mangrove di Kuala Singkawang
}

\section{Isolation and Characterization Nitrogen-Fixing Bacteria from Mangrove Rizosphere in Kuala Singkawang}

\author{
Karina Elwanda Saputri ${ }^{*}$, Nora Idiawati ${ }^{2}$, Mega Sari Juane Sofiana ${ }^{2}$ \\ ${ }_{1}^{1}$ Program Studi Ilmu Kelautan, FMIPA Universitas Tanjungpura, Pontianak, Indonesia \\ ${ }^{2}$ Laboratorium Studi Ilmu Kelautan, FMIPA Universitas Tanjungpura, Pontianak, Indonesia \\ *E-mail : megasofiana86@gmail.com
}

Received : 10 Juni 2021; Accepted: 19 Juni 2021

Published: 31 July (C) Author(s) 2021. This article is open access

\begin{abstract}
Nitrogen nutrients $(N)$ are macro nutrients required by plants. Microorganisms that have the ability to increase the use of $N$ available in the soil are called nitrogen-fixing bacteria. Nitrogen-fixing bacteria can be used as a source of fertilizer as a biological fertilizer. Biological fertilizers are beneficial for restoring and improving soil fertility. The purpose of this study was to obtain isolates of nitrogen-fastening bacteria as ammonia excretion from mangrove rizosphers in Kuala Singkawang. Soil sampling using composite sampling method. Isolation is done directly and enrichment using the pour method on Burk's media. Isolates of nitrogenfastening bacteria isolated from the mangrove rizoosphere amount to 16 isolates that have the ability as nitrogen fasteners. Nitrogen fastening affirmation test results showed 2 out of 16 isolates were highly active in nitrogen tethering. The results of the ammonia excretion test showed from 16 isolates there are 5 isolates capable of producing ammonia. The genus obtained in the study led to the genus Nitrosococcus and Bacillus.
\end{abstract}

Keywords : Mangroves, rhizosphere, biofertilizer, nitrogen-fixing bacteria, ammonia

\begin{abstract}
Abstrak
Unsur hara nitrogen $(\mathrm{N})$ merupakan unsur hara makro yang diperlukan oleh tanaman. Mikroorganisme yang memiliki kemampuan untuk meningkatkan penggunaan $\mathrm{N}$ yang tersedia dalam tanah disebut dengan bakteri penambat nitrogen. Bakteri penambat nitrogen ini dapat dijadikn sebagai sumber pupuk yang sebagai pupuk hayati. Pupuk hayati bermanfaat untuk memulihkan dan meningkatkan kesuburan tanah. Tujuan penelitian ini adalah untuk memperoleh isolat bakteri penambat nitrogen sebagai pengekskresi amonia dari rizosfer mangrove di Kuala Singkawang. Pengambilan sampel tanah menggunakan metode komposit sampling. Isolasi dilakukan secara Langsung dan pengayaaan menggunakan metode tuang pada media Burk's. Isolat bakteri penambat nitrogen yang diisolasi dari rizosfer mangrove berjumlah 16 isolat yang memiliki kemampuan sebagai penambat nitrogen. Hasil uji penegasan penambat nitrogen menunjukkan 2 dari 16 isolat sangat aktif dalam penambatan nitrogen. Hasil dari uji pengekskresi amonia menunjukkan dari 16 isolat ada 5 isolat yang mampu menghasilkan amonia. Genus yang didapatkan pada penelitian yaitu mengarah pada genus Nitrosococcus dan Bacillus.
\end{abstract}

Kata kunci : Mangrove, rizosfer, pupuk hayati, bakteri penambat nirogen, amonia

\section{Pendahuluan}

Lahan salin adalah lahan dengan salinitas tinggi. Lahan salin belum dapat digunakan secara langsung untuk lahan pertanian (Rachman et al., 2018). Salah satu cara pengolahannya adalah dengan pemanfaatan bakteri rizosfer. Bakteri rizosfer merupakan bakteri yang terdapat di sekitar perakaran tanaman. Bakteri ini dapat diperoleh dari hutan mangrove, salah satunya adalah hutan mangrove di Kuala Singkawang, Provinsi Kalimantan Barat. Daerah ini memiliki lahan salin yang potensial untuk pertanian. Bakteri 
Jurnal Laut Khatulistiwa, Vol. 4. No. 2 (Juli, 2021), Hal. 17-21.

rizosfer yang memiliki kemampuan untuk meningkatkan penggunaan $\mathrm{N}$ yang tersedia dalam tanah disebut bakteri penambat nitrogen.

Bakteri penambat nitrogen dalam ekosistem mangrove ada di rizosfer, serasah, pneumatofor, kulit mangrove dan sedimen (Lugomela and Bergman, 2002). Nitrogen dalam bentuk N2 bebas di atmosfer tidak dapat langsung diserap oleh tumbuhan. Tumbuhan menyerap unsur nitrogen dari lingkungannya dalam bentuk senyawa amonia (NH3). Bakteri ini akan menyerap amonia dan mengubahnya menjadi ion-ion nitrat (NO2) yang kemudian dilepaskan ke lingkungannya (Widowati et al., 2012). Banyak spesies bakteri yang memiliki kemampuan sebagai penambat nitrogen, tetapi sangat sedikit yang mampu mengekskresikan nitrogen dalam bentuk amonia sehingga kontribusinya dalam menyediakan nitrogen bagi tanaman juga masih rendah (Dobbelaere et al., 2003). Bakteri penambat nitrogen dapat dijadikan sebagai pupuk yang disebut dengan pupuk hayati.

Pupuk hayati merupakan suatu bahan yang mengandung mikroorganisme yang bermanfaat untuk memulihkan dan meningkatkan kesuburan tanah (Arfarita et al., 2019). Mikroorganisme pupuk hayati berkaitan dengan unsur hara nitrogen $(\mathrm{N})$ yang merupakan unsur hara makro yang diperlukan oleh tanaman. Pemanfaatan pupuk hayati dapat mengurangi kerusakan dan penurunan (degradasi) sumberdaya lahan.
Degradasi lahan dapat menyebabkan lahan pertanian Indonesia menjadi kurang subur yang membuat para petani menggunakan pupuk anorganik untuk mendapatkan hasil panen yang baik. Penggunaan pupuk anorganik dapat meningkatkan unsur-unsur hara dalam tanah. Penelitian yang telah dilakukan bakteri penambat nitrogen genus Azotobacter, Bacillus, Pseudomonas dan Trichoderma berpotensi untuk digunakan sebagai bahan aktif pupuk hayati (Hanudin et al., 2018).

Penelitian ini bertujuan untuk mengetahui isolat bakteri penambat nitrogen di Kelurahan Kuala Kota Singkawang dan genus bakteri penghasil amonia.

\section{Metodologi Penelitian}

\subsection{Waktu dan Tempat Penelitian}

Penelitian ini telah dilakukan pada bulan Agustus - Desember 2020. Pengambilan sampel rizosfer mangrove dilakukan di kawasan mangrove Kelurahan Kuala, Kecamatan Singkawang Barat, Kota Singkawang. Uji aktivitas metabolik dan identifikasi bakteri rizosfer mangrove dilakukan di Laboratorium Mikrobiologi, UPTPMHP Provinsi Kalimantan Barat.

\subsection{Analisis Data}

Alat-alat yang digunakan pada penelitian ini yaitu autoklaf, alumunium foil, bunsen, botol vial, cawan petri, corring, cover glass, beaker glass, erlenmeyer, Global Positioning

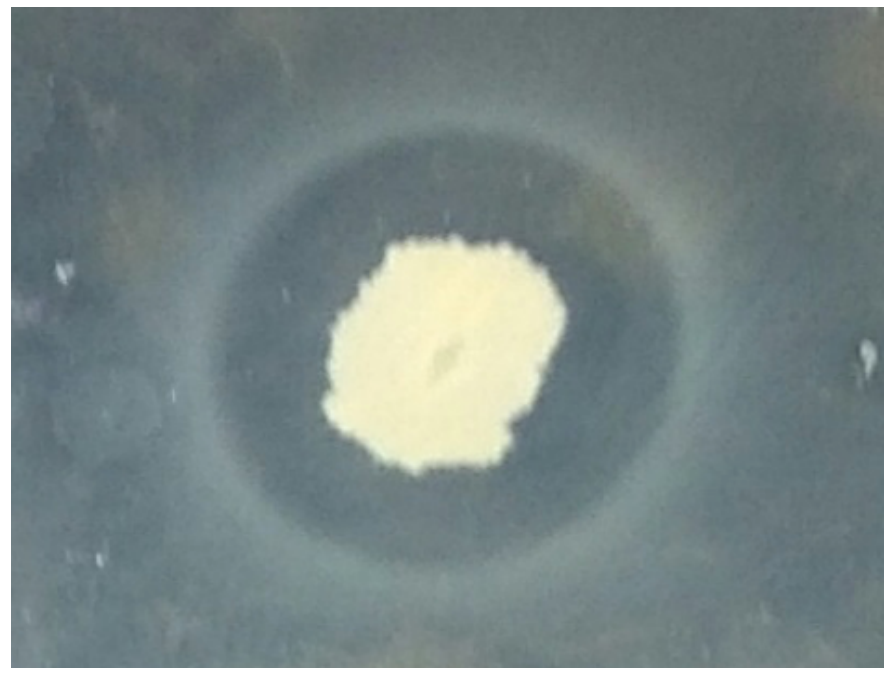

Gambar 1. Zona bening isolat bakteri penambat nitrogen 
Jurnal Laut Khatulistiwa, Vol. 4. No. 2 (Juli, 2021), Hal. 17-21.

system (GPS), jangka sorong, jarum ose, kamera, laminar airflow (LAF), mikropipet, mikroskop, $\mathrm{pH}$ tanah, pipet tetes, plastik sampel, spatula, shaker, rak tabung reaksi, tabung reaksi, neraca analitik, tissue dan vortex.

Bahan-bahan yang digunakan pada penelitian ini yaitu akuades $\left(\mathrm{H}_{2} \mathrm{O}\right), \alpha$-naphthol, agar, ammonium sulfat ( $\left.\left(\mathrm{NH}_{4}\right) \mathrm{SO}_{4}\right)$, bakto agar, besi (II) sulfat $\left(\mathrm{FeSO}_{4} \cdot \mathrm{H}_{2} \mathrm{O}\right)$, dektrosa, dipotassium fosfat $\left(\mathrm{K}_{2} \mathrm{HPO}_{4}\right)$, d(-)manitol, ekstrak ragi, glukosa, hidrogen peroksida $\left(\mathrm{H}_{2} \mathrm{O}_{2}\right)$, iodin, kalium hidroksida $(\mathrm{KOH})$, kalsium fosfat $\left(\mathrm{Ca}\left(\mathrm{PO}_{4}\right)\right)$, kristal violet, magnesium sulftat hepatohidrat $\left(\mathrm{MgSO}_{4} .7 \mathrm{H}_{2} \mathrm{O}\right)$, mangan (II) sulfat $\left(\mathrm{MnSO}_{4} \cdot \mathrm{H}_{2} \mathrm{O}\right)$, methyl red, natrium sulfat $\left(\mathrm{Na}_{2} \mathrm{SO}_{4}\right)$, potassium dihidrogen fosfat $\left(\mathrm{KH}_{2} \mathrm{PO}_{4}\right)$, sampel sedimen mangrove, sodium molibdat $\left(\mathrm{Na}_{2} \mathrm{MoO}_{4}\right)$, Simson's Citrate Agar (SCA), Sugar Iron Agar (TSIA), safranin, sukrosa, Tetra Kit, Urea Base Agar.

\subsection{Pengambilan Sampel}

Pengambilan sampel rizosfer mangrove menggunakan Teknik Komposit Sampling (Emine et al., 2015). Penentuan stasiun penelitian dilakukan dengan metode purposive sampling. Sampel di ambil sekitar rizosfer mangrove $(10-20 \mathrm{~cm})$ menggunakan coring dan dilakukan 10 kali ulangan pada setiap titik stasiun. Sampel kemudian dikompositkan dan disimpan dalam botol vial steril kemudian sampel dibawa ke laboratorium untuk diisolasi.

\subsection{Isolasi Bakteri Penambatan Nitrogen}

Isolasi bakteri dilakukan secara langsung dan pengayaan menggunakan metode tuang. Sampel ditimbang sebanyak 10 gr dan dilarutkan dalam $90 \mathrm{~mL}$ akuades steril dan medium Burk's cair dalam erlenmeyer. Sampel divortex dan dilakukan pengenceran 10-1 hingga $10^{-5}$ dengan $9 \mathrm{~mL}$ akuades steril. Suspensi sampel dari masing-masing pengenceran $10^{-3}, 10^{-4}$ dan $10^{-5}$ diambil sebanyak $1000 \mu \mathrm{l}$ dan ditambahkan ke cawan petri yang bersi medium Burk's dengan komposisi (10 gr dekstrosa, 0,41 gr $\mathrm{KH}_{2} \mathrm{PO}_{4}$, 0,52 gr $\mathrm{K}_{2} \mathrm{HPO}_{4}, 0,05$ gr Na$_{2} \mathrm{SO}_{4}, 0,2$ gr KCl, 0,1 gr $\mathrm{MgSO}_{4} \cdot 7 \mathrm{H}_{2} \mathrm{O}, 0,005$ gr $\mathrm{FeSO}_{4} \cdot \mathrm{H}_{2} \mathrm{O}, 0,0025$ gr $\mathrm{Na}_{2} \mathrm{MoO}_{4}$ dan 20 gr agar) (Singh et al., 2013).
Bakteri yang tumbuh diamati setiap hari selama 48 jam pada suhu $32^{\circ} \mathrm{C}$ (Hamza et al., 2017).

\subsection{Uji Penambat Nitrogen}

Uji penambat nitrogen dilakukan dengan mengambil sebanyak 1 ose dan diinokulasikan pada medium Burk's. Isolat kemudian di inkubasi pada suhu $30^{\circ} \mathrm{C}$ selama 5-7 hari (Widawati and Suliasih, 2018). Isolat yang membentuk zona bening menunjukkan bakteri dapat menambat nitrogen.

\subsection{Uji Konsentrasi Amonia}

Uji konsentrasi amonia dilakukan secara kualitatif menggunakan reagen Tetra Kit. Perubahan warna yang terjadi diamati dan dibandingkan dengan Tetra Kit standar Bar (Arfarita, et al., 2019).

\subsection{Karakteristik dan Identifikasi Isolat Bakteri Terpilih}

Isolat bakteri yang memiliki aktivitas metabolik terbaik dikarakterisasi dan diidentifikasi dengan uji biokimia berdasarkan metode metode Bergey's Manual and Systematic of Bacteriology (Holt et al., 1994). Pengujian biokimia yang dilakukan di antaranya pewarnaan gram, oksidase, urease, katalase, sitrat, metabolisme karbohidrat, MRVP, motilitas, oksidasi-fermentasi dan $\mathrm{H}_{2} \mathrm{~S}$.

\section{Hasil dan Pembahasan}

\subsection{Hasil}

Isolat yang diperoleh pada penelitian ini merupakan isolat bakteri penambat nitrogen yang telah ditumbuhkan pada media bebas nitrogen yaitu media Burk's. Media ini tidak mengandung unsur nitrogen sehingga hanya bakteri penambat nitrogen yang dapat tumbuh pada media tersebut (Hartono dan Jumadi, 2014). Hasil isolat bakteri rizosfer mangrove dengan metode cawan tuang diperoleh 5 isolat, sedangkan dengan pengayaan diperoleh 11 isolat yang menunjukkan morfologi koloni bakteri yang berbeda.

Uji penambat nitrogen menunjukkan dari 16 isolat bakteri terdapat 2 isolat yang membentuk zona bening (holo zone) disekeliling koloni seperti pada Gambar 4.1.

Adanya zona bening (holo zone) disekitar koloni menunjukkan bahwa isolat bakteri 
Jurnal Laut Khatulistiwa, Vol. 4. No. 2 (Juli, 2021), Hal. 17-21.

Tabel 1. Indeks Penambat Nitrogen

\begin{tabular}{cc}
\hline Isolat & Luas Holo Zone $(\mathrm{cm})$ \\
\hline KM206 & 0,6 \\
KM103 & 0,3 \\
\hline
\end{tabular}

memiliki kemampuan dalam menambat nitrogen. Isolat bakteri yang memiliki kemampuan menambat nitrogen paling besar yaitu isolat KM206 dan KM103 (Tabel 3.1).

\subsection{Pembahasan}

Bakteri dapat mengubah energi menjadi bahan organik tanah dalam bentuk yang bermanfaat bagi organisme. Bakteri pengurai memiliki peran penting, terutama dalam imobilisasi nutrisi dan dapat mencegah hilangnya nitrogen dari daerah rizosfer (Handayanto dan Hairiah, 2007). Salah satu bentuk bakteri pengurai yang dapat mencegah hilang nitrogen dalam tanah yaitu bakteri penambat nitrogen. Bakteri penambat nitrogen dapat menangkap $\mathrm{N}$ dari udara dan mengubahnya menjadi $\mathrm{NH}_{3}$ dengan menggunakan enzim nitrogenase, kemudian $\mathrm{NH}_{3}$ diubah menjadi glutamin atau alanin sehingga bisa diserap oleh tanaman dalam bentuk $\mathrm{NO}_{3}$ dan $\mathrm{NH}_{4}{ }^{+}$(Zulfarina et al., 2017).

Uji penambat nitrogen dari isolat bakteri rizosfer mangrove telah banyak dilaporkan. Beberapa diantaranya yaitu isolat bakteri dari tanah hutan mangrove Sungai Peniti, Kabupaten Mempawah (Kabul et al., 2019) dan isolat bakteri dari tanah kawasan mangrove Wonorejo Surabaya (Metasari et al., 2012) menunjukkan adanya aktivitas bakteri sebagai penambat nitrogen. Penelitian ini menunjukkan bahwa isolat bakteri rizosfer mangrove dari Kelurahan Kuala Kota Singkawang berpotensi sebagai penambat nitrogen.

Uji konsentrasi amonia dari 16 bakteri pengikat nitrogen dilakukan dengan metode kualitatif menggunakan Tetra Kit. Metode ini digunakan untuk memperoleh kemampuan isolat bakteri menghasilkan amonia dengan konsentrasi tinggi. Pengamatan dilakukan dengan melihat perubahan warna dalam media kultur. Perubahan warna pada media terjadi karena adanya $\mathrm{NH}_{3}$ yang bersifat basa sehingga menyebabkan warna kuning pada indikator bromothymol menghijau (Arfarita et al., 2019). Kemudian diamati perubahan warna pada media kultur lalu dibandingkan dengan warna pada Tetra Kit standar Bar. Uji kualitatif penghasil amonia dilakukan terhadap 16 isolat bakteri rizosfer mangrove. Hasilnya menunjukkan bahwa isolat KM104, KM201, KM202, KM206 dan KM207 memiliki kemampuan penghasil amonia yang dilihat dari warna yang berubah menjadi hijau tua.

Karakterisasi isolat bakteri rizosfer mangrove yang memiliki aktivitas metabolik terbaik yaitu KM104 dan KM207. Isolat bakteri selanjutnya diidentifikasi dengan uji biokimia untuk mengetahui karakteristik isolat bakteri tersebut. Pengujian biokimia yang dilakukan di antaranya pewarnaan gram, oksidase, urease, katalase, sitrat, metabolisme karbohidrat, MRVP, motilitas, oksidasi-fermentasi dan $\mathrm{H}_{2} \mathrm{~S}$. Hasil penelitian ini secara umum menyimpulkan jenis isolat yang diperoleh mengarah pada genus bakteri Nitrosococcus dan Bacillus.

\section{Kesimpulan}

Isolat bakteri rizosfer mangrove pada Kelurahan Kuala Kota Singkawang diperoleh 16 isolat. Hasil uji penegasan penambat nitrogen menunjukkan 2 dari 16 isolat yang mampu menambat nitrogen. Hasil dari uji pengekskresi amonia menunjukkan dari 16 isolat ada 5 isolat yang mampu menghasilkan amonia. Genus bakteri yang didapatkan yaitu mengarah ke genus Nitrosococcus dan Bacillus.

\section{Ucapan Terima Kasih}

Terima kasih kepada Kedua Orang Tua dan keluarga yang selalu memberi semangat dan dukungan serta do'a kepada penulis dan juga terima kasih kepada beasiswa PPA terkait yang membantu dalam menyelesaikan riset ini.

\section{Daftar Pustaka}

Arfarita, N., A. Muhibbudin and T. Imai. 2019. Exploration of indigenous free nitrogenfixing bacteria from rhizosphere of Vigna radiata for agricultural land treatment, 
Jurnal Laut Khatulistiwa, Vol. 4. No. 2 (Juli, 2021), Hal. 17-21.

Journal of Degrdated and Mining Lands Management. 6 (2):1617-1623

Dobbelaere, J., M.S. Gentry, R.L Hallberg dan Y. Barral. 2003. Phosphorylation-Dependent Regulation of Septin Dynamics During the Cell Cycle. Journal Dev Cell. 4(3): 345-57

Emine, S., N. Zainol, J. Salihon and P. Convey. 2015. Mangrove Rhizosphere Soils: A Unique Natural Source of PravastatinProducing Penicillium Microfungi. Journal of Extensive Research. (5): 79-87

Hamza, A. T., H. Zebiba, M. Rediet, A. Petros and B. Tesfaye. 2017. Isolation and Characterization of Nitrogen Fixing Bacteria from Rhizospher Soil Isolation and Characterization of Nitrogen Fixing Bacteria from Rhizospher Soil Collected from Shell Mele Agricultural. Journal of Agricultural Science and Food Technology. 3(7): 117-124.

Handayanto, E. dan K. Hairiyah. 2007. Biologi Tanah, Yogyakarta, Pustaka Adipura.

Hanudin, K. Budiarto dan B. Mawarto. 2018. Potensi Beberapa Mikroba Pemacu Pertumbuhan Tanaman sebagai Bahan Aktif Pupuk dan Pestisida Hayati, Jurnal Litbang Pertanian, Vol.37 (2), Hal: 59-70

Hartono dan O. Jumadi. 2014. Seleksi dan Karakterisasi Bakteri Penambat Nitrogen Non Simbiotik Pengekskresi Amonium Pada Tanah Pertanaman Jagung (Zea mays L.) dan Padi (Oryza sativa L.) Asal Kabupaten Barru, Sulawesi Selatan, Indonesia, Jurnal Sainsmat, Vol.3(2), Hal: 143-153

Holt, J.G., N.R. Krieg, P.H.A., Sneath, J.T. Staley and S.T. Williams. 1994. Bergey's Manual of Determinative Bacteriology, Ed ke-9, Williams and Wilkins Baltimore, USA

Kabul, S., Rafdinal dan Rahmawati. 2019. Eksplorasi Bakteri Penambat Nitrogen dari Tanah Hutan Mangrove Sungai Peniti, Kabupaten Mempawah. Jurnal Protobiont, Vol. 8(1), Hal. 52-58.

Lugomela, C. and B. Bergman. 2002. Biological N2-fixation on Mangrove Pneumatophores: Preliminary Observations and Perspectives. Journal Ambio. 1(3) : 6-12.
Metasari, K. 2012. Eksplorasi Bakteri Penambat Nitrogen Non Simbiosis Dari Tanah Kawasan Hutan Mangrove Wonorejo Surabaya. Program Studi Biologi Fakultas Sains dan Teknologi Universitas Airlangga, Jurnal, Surabaya.

Rachman, A., A. Dariah dan S. Sutono. 2018. Pengelolaan Sawah Salin Berkadar Garam Tinggi. IAARD PRESS. Jakarta.

Singh, S., P.B. Mazumder, M.K. Bhattacharjee, and Sharma. 2013. Determination of Nitrogen Fixing Capacity of Bacteria Isolated from the Rhizosphere soil of Crotolaria pallida from the Valley Districts of Manipur India, Journal of Pharmacy and Biological Sciences (IOSR-JPBS). 8 (4): 2024

Widawati, S., and Suliasih. 2018. The Effect of Plant Growth Promoting Rhizobacteria (PGPR) on Germination and Seedling Growth of Sorghum bicolor L. Moench. Journal Earth Environ. 166 : 1-11

Widowati, Asnah dan Sutoyo. 2012. Pengaruh Penggunaan Biochar dan Pupuk Kalium Terhadap Pencucian dan Serapan Kalium pada Tanaman Jagung, Jurnal Buana Sains. 12 (1): 83-90.

Zulfarina, Z., I. Rusmana, N.R. Mubarik and D.A. Santosa. 2017. The Abundance of Nitrogen Fixing, Nitrifying, Denitrifying and Ammonifying Bacteria in the Soil of Tropical Rainforests and Oil Palm Plantations in Jambi, Journal Makara of Science. 21 (4): 187-194 